\title{
Notes about Censorship and Self-Censorship in the Biography of the Prophet Muhammad*
}

\author{
Notas sobre censura y auto-censura \\ en la biografía del Profeta Muhammad
}

\author{
Michael Lecker \\ Jerusalem
}

\begin{abstract}
The study of the medieval literary output about Muhammad's life should go hand in hand with the study of his history, for which we have rich evidence in a variety of sources. Ibn Ishāa's biography of Muhammad and its epitome by Ibn Hishām were products of their time. A case of self-censorship applied by one of Ibn Ishāa's informants and two cases of censorship applied by Ibn Hishām, who omitted many of his predecessor's materials, contribute to a better understanding of the social and political context of the biography.
\end{abstract}

Key words: Muhammad; Sìra; Biography; Abbasids; Umayyads; Medina; Hīra; Censorship; Hadith.
El estudio de la producción literaria medieval sobre la vida de Muhammad debe ir de la mano del estudio de su historia, empresa para la que disponemos de rica información en una variedad de fuentes. La biografía de Muhammad por Ibn Isḥāq y su epítome por Ibn Hišām fueron productos de su época. Un caso de auto-censura aplicado por uno de los informantes de Ibn Isḥāq y dos casos de censura aplicados por Ibn Hišām, quien omitió muchos de los materiales de su predecesor, contribuyen a una mejor comprensión del contexto social y político de la biografía del Profeta.

Palabras clave: Muhammad; Sìra; biografía; 'abbāsíes; omeyas; Medina; Hịra; censura; hadiz.

The most popular medieval biography of the prophet Muhammad was compiled by Ibn Ishạa (d. ca. 151/768) and is known to us through its epitome by Ibn Hishām (d. ca. 218/833). As a history book it is not free of weaknesses, among them editorial practices. The following article deals with rather elusive editorial practices, namely censorship and self-censorship. Both deprive us of certain details or accounts - unless they can be found elsewhere in the vast Islamic literature. But at the same time censorship and self-censorship reveal the attitudes of

*I am grateful to the anonymous reviewers for their thorough commentaries. 
those who applied them and shed some light on the social and political context in which Muhammad's biography emerged. The biography was a product of its time, and as such it reflected the concerns and sensitivities of Muhammad's companions, their descendants and all those who contributed to its compilation.

The first case to be discussed is one of self-censorship. It relates to an act of disobedience to Muhammad. The account about it survived, but the identity of the two perpetrators was not disclosed to Ibn Ishāa and remained secret, no doubt in order to spare their families the embarrassment. The other two cases represent two different categories of the materials that Ibn Hishām expunged from the biography due to the censorship he applied to Ibn Ishāq's biography of Muhammad. One of the two censored accounts implies that before his Mission, Muhammad was an idol worshipper, while the other relates to a harlot in pre-Islamic Yathrib (Medina) whose jinnī announced the advent of Muhammad's Mission.

\title{
The two who disobeyed Muḥammad
}

The following act of disobedience to Muhammad occurred during the Tabūk expedition $(9 / 630):^{1}$

\begin{abstract}
When the Messenger of Allāh passed al-Hijr, he alighted in it and the men got water from its well. When they returned in the evening, the Messenger of Allāh said, 'Do not drink any of its water nor use it for ablution. If you have used any of it to prepare dough, then feed it to the camels and eat none of it. Let none of you go out at night alone without a companion'. The men did as they had been told, except two men of the Banū Sāeida: one went out to relieve himself, and the other to look for a camel of his. The one who went to relieve himself was choked where he was relieving himself and the one who went to look for a camel of his was carried away by the wind, which cast him on the two mountains of Tayyi'. The Messenger of Allāh was told of this and said, 'Have I not forbidden you to go out without a companion?' Then he prayed for the man who was choked where he was relieving himself and he recovered; the other who landed in the two mountains of Tayyi' was delivered to the Messenger of Allāh by the Tayyi' as a gift when he came to Medina. The story about the two men comes from 'Abdallāh ibn Abī Bakr, from 'Abbās ibn Sahl ibn Sa'd al-Sā'idī. 'Abdallāh ibn Abī Bakr told me that 'Abbās
\end{abstract}

1 The account discussed here did not escape Josef Horovitz: see Horovitz, The Earliest Biographies of the Prophet and their Authors, p. 44. 
had revealed to him the names of the two men but he ['Abbās] asked that they be kept secret, so 'Abdallāh refused to tell me their names. ${ }^{2}$

Ibn Isḥāq's immediate informant, ‘Abdallāh ibn Abī Bakr (d. $130 / 747-748$ or $135 / 752-753),{ }^{3}$ belonged to the Khazraj, more precisely to the Najjār branch of Khazraj. ${ }^{4}$ Abdallāh received the account from 'Abbās ibn Sahl ibn Sa'd (d. ca. 120/738), who belonged to the Sā'ida branch of Khazraj. The two unspecified protagonists of the account were also from the Sā'ida, which explains why 'Abbās asked 'Abdallāh not to disclose their identity: he spared the perpetrators' offspring the embarrassment.

Further details about the account are relevant for us here. 'Abbās ibn Sahl ibn Sa'd al-Sāidì probably received it from a close relative of his. A variant found in Wāqidī's Kitāb al-maghāzī links it to another event that is similarly related to the Tabūk expedition. ${ }^{5}$ It concerns a woman's orchard in Wādī 1-Qurā which Muhammad and his companions visited on their way to Tabūk. Muhammad's companion Abū Humayd al-Sā ${ }^{e} i_{1}{ }^{6}$ transmitted to ${ }^{~ A b b a ̄ s ~ t h e ~ a c c o u n t ~ a b o u t ~ t h e ~ o r c h a r d, ~}{ }^{7}$ and one assumes that he also transmitted to him the account about the disobedience discussed here. 'Abbās must have had a special interest in the Tabūk expedition because his father, Sahl ibn Sa'd, had participated in it. According to Sahl's own testimony, he was then the youngest participant (kuntu aṣghar aṣhābì). Muhammad prohibited the drinking of the water, but allowed the warriors to feed the camels with dough paste that had been prepared with this water before he gave his

${ }^{2}$ Ibn Hishām, Das Leben Muhammeds nach Muhammed ibn Ishâk, bearbeitet von Abd el-Malik ibn Hischâm, pp. 898-899; below, Appendix I; Guillaume, The Life of Muhammad: A Translation of Ibn Ishàq's Sirat Rasūl Allāh, p. 605.

${ }^{3} \mathrm{Ibn}$ Sa d, al-Tabaqāt al-kubräa: al-qism al-mutammim li-tābi'ī ahl al-Madīna waman ba'dahum, ed. Ziyād Muhammad Manșūr, p. 283; Sezgin, Geschichte des arabischen Schrifttums, I, p. 284; Horovitz, The Earliest Biographies of the Prophet, Index.

${ }_{4}$ Ibn Hazm, Jamharat ansāb al-'arab, p. 348.

${ }^{5}$ Al-Wāqidī, Kitāb al-maghāzì, III, pp. 1005-1006; below, Appendix II.

${ }^{6}$ There are several versions concerning his name, probably because he was better known through his agnomen Abū Humayd than through his own name and that of his father.

7 See e.g. Ibn Zanjawayh, Kitāb al-amwāl, III, pp. 1076-1077, no. 2001; below, Appendix III. In Muslim's Șahị the account is combined with several other accounts revolving around the Tabūk expedition. Again the isnād includes 'Abbās ibn Sahl $\leftarrow \mathrm{Abu}$ Humayd, which is the part that concerns us here; Muslim ibn al-Hajajāj, Sahịh, IV, pp. 17851786 (Kitāb al-fadà'il, no. 11); below, Appendix IV. 
order. The emaciated camels that Sahl fed that dough became the weakest in the herd. ${ }^{8}$

The companion Abū Humayd al-Să'idī, who died at the end of Mu'âwiya's reign (41/661-60/680) or the beginning of Yazìd I's reign $(60 / 680-64 / 683),{ }^{9}$ is said to have been Sahl's paternal uncle. While their precise family link cannot be established with any certainty, we may assume that they were closely related and that the two who disobeyed Muhammad were not only fellow Sāeidīs but also their family members.

$$
* * *
$$

Let us turn now to the two cases of editorial censorship applied by Ibn Hishām in his epitome of Ibn Ishạā's biography. The relevant accounts are found in the recension (i.e. version or textual tradition, ${ }^{10}$ Arabic: riwāya) of Yūnus ibn Bukayr (d. 199/815). Part of Ibn Bukayr's recension is available to us through fragments published independently by Muḥammad Ḥamīdullāh in 1976 and by Suhayl Zakkār in 1978. Each of the two editions includes two fragments found in the Qarawiyyin library in Fez and a single fragment found in the Zāhiriyya library in Damascus. While the two fragments belong to Ibn Bukayr's recension, the single fragment belongs to that of Muhammad ibn Salama (d. 192/807). The Qarawiyyīn fragments, unlike the Zāhiriyya one, are not homogeneous and include many items from authorities other than Ibn Ishāq. ${ }^{11}$ The two fragments also include accounts that are not linked

8 Wāqidī, Maghāài, III, p. 1007. When Muhammad died, Sahl was fifteen years old; Ibn Hajar, al-Ișāba fi tamyìz al-ṣahāba, III, p. 200.

9 See e.g. Ibn Hajar, Ișāba, VII, pp. 94-95.

10 The term textual tradition was used by Jones, "The Maghāzì literature," p. 346. He used it side by side with the term recension. Jones used the term version with reference to Ibn Hishām: "Ibn Hishām's version of the text".

${ }^{11}$ Out of 473 articles in Hamidullāh's edition some 180 go back to sources other than Ibn Ishāāq; Muranyi, "Ibn Ishāq's Kitāb al-Maḡāzì in der Riwāya von Yūnus b. Bukair: Bemerkungen zur frühen Überlieferungsgeschichte," p. 218. Al-Suhaylī quoted Ibn Bukayr's version 52 times, but only 15 of his references are found in the edited fragments; Jarrar, Die Prophetenbiographie im islamischen Spanien: Ein Beitrag zur Überlieferungsund Redaktionsgeschichte, pp. 207-208. Ibn Bukayr was himself a compiler of a Maghāzi book; Jarrar, Die Prophetenbiographie im islamischen Spanien, passim. Schoeler, Charakter und Authentie der muslimischen Überlieferung über das Leben Mohammeds, pp. 5051 suggested that this type of transmitter/author (Überlieferer/Verfasser) be referred to as adaptor (Bearbeiter). See also Schoeler, The Genesis of Literature in Islam from the Aural to the Read, p. 77. Surprisingly, Ibn Isḥāq, Sìrat Ibn Ishạq al-musammāt bi-kitāb al-mub- 
to Muhammad's biography, such as those concerning the marriages of 'Alī's daughters Umm Kulthūm and Zaynab. ${ }^{12}$ However, such accounts probably existed in other recensions of Ibn Ishāq's biography as well. ${ }^{13}$ Alfred Guillaume observed regarding the Qarawiyyin manuscript: "The importance of this manuscript lies in those passages which restore to us material that Ibn Hishām omitted from his text for the reasons which he has given in his Introduction to his edition" (see below) ${ }^{14}$ Sadun Mahmud al-Samuk pointed out the manuscript's unorthodox approach regarding Muhammad's life before the Mission. ${ }^{15}$

The differences in Ibn Ishāa's recensions notwithstanding, one assumes that the two problematic accounts from Ibn Bukayr's recension that are discussed here were also included in Ziyād al-Bakkā'ì's (d. 183/799) recension on which Ibn Hishām based his epitome. Ibn Hishām stated that in certain cases he had applied censorship. The first paragraph in his epitome purports to provide the pedigree of Muhammad going back to Adam, while the second paragraph reads as follows:

tada' wa-l-mab'ath wa-l-maghāzī, p. 1 starts with the following isnād: qāla Abū Muhammad 'Abd al-Malik ibn Hishām hādhā kitāb sìrat rasūli llāh șallā llāhu' 'alayhi wa-sallama. But the isnād and the following passage which concerns Muhammad's pedigree are missing in Zakkār's edition and probably do not belong to the manuscript to which they were attached. It should be added that a comparison between the Fez manuscript and Ibn Hishām's book has also been carried out by 'Abd al-'Azīz al-Dūrī in his Dirāsa fì sìrat al-nabì wamu'allifiha Ibn Ishāq , Baghdad, 1965. The book is unavailable to me.

${ }_{12}$ Guillaume, New Light on the Life of Muhammad, pp. 50-52.

13 Al-Bakkā'î's full recension included Ibn Isḥāq's Kitāa al-khulafă'; al-Samuk, Die historischen Überlieferungen nach Ibn Ishāq. Eine synoptische Untersuchung, p. 85, n. 4.

${ }_{14}$ Guillaume, New Light on the Life of Muhammad, p. 10. Cf. Raven, "Sira and the Qur'ān," p. 33: "Ibn Hishām made judgments about the theological 'purity' in the texts he selected and left out passages that he found offensive... Two striking stories that Ibn Hishām had not included are those about Muhammad's intended suicide (al-Ṭabarī, Ta'rīkh al-rusul wa-l-mulük, ed. de Goeje et alii, I, p. 1147) and the 'satanic verses'; al-Tabari, Ta'rìkh, I, pp. 1192-1196)". But al-Tabarī's text relating to the intended suicide is not from Ibn Ishāq. On the topics of suicide and the "Satanic Verses" see Rubin, The Eye of the Beholder: The Life of Muhammad as Viewed by the Early Muslims, pp. 113-114 and pp. 156166 , respectively.

15 Al-Samuk, Die historischen Überlieferungen nach Ibn Ishāq, pp. 97-98: "Muhammad wird... - besonders für die Zeit vor seiner Berufung - mit den nach Ibn Isḥāq wiedergegebenen Überlieferungen sehr menschlich beschrieben, hier ist der Prophet nicht schon in Mekka - wie nach vielen anderen Quellen - als ein Mensch mit übernatürlichen Eigenschaften dargestellt". Also al-Samuk, Die historischen Überlieferungen nach Ibn Ishāa, p. 159: "Das Bild des Propheten vor seiner Berufung wird hier in den Überlieferungen Ibn Ishāq's nicht 'überhöht' gezeichnet oder legendär verklärt, es finden sich im Gegenteil Berichte, die von anderen Überlieferern - wohl aus Gottesfurcht - fortgelassen worden waren". 
I begin this book, Allāh willing, with the mention of Ishmael son of Abraham and those of his offspring who bore the Messenger of Allāh and their descendants, first things first, from Ishmael to the Messenger of Allāh. [I also mention] their story to the extent that it is available, leaving out the other offspring of Ishmael for the sake of brevity until [I arrive at] the account of the biography of the Messenger of Allāh, leaving out some of what Ibn Ishāq mentioned in this book. To wit, matters in which the Messenger of Allāh is not mentioned, [matters] concerning which no Qur'ân verses were revealed, and those that are not the cause, the explanation or the proof of something in this book. The reason is the above mentioned wish for brevity. [Also left out are] verses which he [Ibn Ishāq] mentioned but none of the connoisseurs of poetry I met was acquainted with, things that are either disgraceful to talk about (yashnu'u l-hadith bihi), or such that may distress certain people (yasü'u ba 'da l-nās dhikruhu), or such that were not confirmed to us by al-Bakkā'ì. Allāh willing, I shall fully adduce all the rest within the limits of the available transmission and knowledge. ${ }^{16}$

Two of the above mentioned categories clearly indicate censorship, namely the disgraceful and distressing matters. Johann Fück recorded Ibn Hishām's own reports regarding the omission of improper verses and verses which assault the Prophet. Fück correctly included the verses in the category of things that are disgraceful to talk about. $\mathrm{He}$ also included in the same category the affair of the Satanic Verses (or "the Gharāniq episode" as he called it). As to the second category, that of things which may distress certain people, Fück referred to Ibn Hishām's omission of the account about the capture of Muhammad's uncle ${ }^{~ A b b a ̄ s ~ i n ~ t h e ~ b a t t l e ~ o f ~ B a d r . ~}{ }^{17}$

${ }^{16}$ Ibn Hishām, Das Leben Muhammeds, p. 4; below, Appendix V; Guillaume, The Life of Muhammad, pp. 3, 691.

${ }_{17}$ Fück, Muhammad ibn Ishaq: Literarhistorische Untersuchungen, p. 35: “... anstössige Stellen; solche, die einige Menschen verletzen könnten". The verses of the former category are improper verses omitted by Ibn Hishām according to his own statement: Ibn Hishām, Das Leben Muhammeds, pp. 170, 1. 3; 274, 1. 18; 523, 1. 13; 524, 1. 9; 572, 1. 15; 581, 1. 16; 644, 1 . 9; 939, 1. 4; also verses in which the Prophet is attacked, such as 532, 1. 16. In 517, 1. $20 \mathrm{Ibn}$ Hishām changed an insulting word (in fact he changed two words). See also Horovitz, The Earliest Biographies of the Prophet, p. 81 ("... besides allegations whereof the mention was malicious, or likely to be disagreeable to certain people"); Schoeler, Charakter und Authentie, p. 50; Schoeler, The Genesis of Literature in Islam, p. 77 ("indecent passages; passages that might be injurious to certain individuals"); al-Samuk, Die historischen Überlieferungen nach Ibn Ishāq, p. 157: “... Dinge und Ereignisse, von denen zu berichten hässlich ist, oder die andere Menschen verletzen könnten". Nöldeke, "Die Tradition über das Leben Muhammeds," p. 166, n. 2 has already noticed Ibn Hishām's occasional omission of verses of both the Muslims and their opponents. Regarding 'Abbās's capture in Badr, see Nöldeke, "Die Tradition über das Leben Muhammeds," pp. 167-168. A remark about technology can be made at this point. In order to trace Ibn Hishām's omissions of verses which he considered as improper 
Other examples of accounts and problematic expressions that were expunged by Ibn Hishām can be mentioned briefly. Muhammad, when he was still a young shepherd, intended to obtain illicit sexual pleasure, but Allāh protected him from it. ${ }^{18}$ During the lapse of revelation (fatrat al-wahy) Muhammad said to himself: "I am afraid my associate [i.e. the angel] has become hateful of me (qalānī) and has deserted me (wadda anī)" ${ }^{19}$ A subtler case of censorship concerns Muhammad's worship of idols (on which see more below). In a passage summarizing Muhammad's early years with his uncle Abū Ṭālib we find that he grew up protected by Allāh from the filth of the Jâhiliyya and its vices, "while he was still following the religion of his tribe" (wa-huwa 'ala dīn qawmihi). Ibn Hishām adduced this account without this crucial statement. ${ }^{20}$ This very expression, wa-huwa 'alà dìn qawmihi, appears in an account about Muhammad's wuqūf in Mt. 'Arafät which is found in Ibn Hishām with a less problematic phrasing: qabla an yanzila alayhi $l$-wahy or before the revelation. ${ }^{21}$ Yet another small editorial change by Ibn Hishām can be added. Al-Samuk noticed the difference between Ibn Bukayr and Ibn Hishām regarding 'Abd al-Mutțalib's action upon Muhammad's birth. The former said that 'Abd al-Muttalib took the newborn child to the idol Hubal inside the Ka'ba (fa-adkhalahu 'ala Hubal fi jawfi l-Ka'ba), while the latter omitted Hubal's mention: 'Abd al-Mutțalib merely took the child to the Ka'ba (fa-dakhala bihi l-Ka'ba). ${ }^{22}$ Other cases of Ibn Hishām's censorship include the

one can nowadays employ an electronic version of his book (using the Internet, or electronic text repositories such as al-Maktaba al-shāmila or al-Jāmi' al-kabirr) and look for the Arabic verb aqdha a, "to revile, vilify" that appears eight times, and for its feminine form aqdha at that appears once. But of course Fück has already pointed out these verses.

18 Rubin, The Eye of the Beholder, pp. 86-87; Ibn Ishāq, Sìra, ed. Hamīdullāh, pp. 5859, no. 57; Ibn Ishāā, Kitāb al-siyar wa-l-maghāzì, ed. Żakkār, pp. 79-80.

19 Rubin, The Eye of the Beholder, pp. 116-117; Ibn Isḥāq, Sìra, ed. Hamiadullāh, p. 115, no. 166; Ibn Isḥāq, Kitāb al-siyar wa-l-maghāzī, ed. Zakkār, p. 135.

${ }^{20}$ Rubin, The Eye of the Beholder, pp. 87, 89; Ibn Ishāq, Sìra, ed. Hamīdullāh, p. 57, no. 54; Ibn Isḥāq, Kitāa al-siyar wa-l-maghāzī, ed. Zakkār, p. 78; Ibn Hishām, Das Leben Muhammeds, p.117.

${ }^{21}$ Ibn Isḥāq, Sìra, ed. Ḥamīdullāh, p. 76, no. 92; Ibn Isḥāq, Kitāb al-siyar wa-l-maghāzī, ed. Zakkār, p. 98 ; Ibn Hishām, Das Leben Muhammeds, p. 129. Cf. Rubin, The Eye of the Beholder, pp. 88-89 (who may have overlooked the account in Ibn Hishām). Rubin adduced from other sources several alternatives to the problematic phrase.

${ }^{22}$ Al-Samuk, Die historischen Überlieferungen nach Ibn Ishāq, p. 95; Ibn Isḥāq, Sìra, ed. Ḥamīdullāh, p. 22, no. 28; Ibn Isḥāq, Kitāb al-siyar wa-l-maghāzī, ed. Zakkār, p. 45; Ibn Hishām, Das Leben Muhammeds, p. 103. 
above mentioned account on the "Satanic Verses" (Ibn Ishāa's account does not include the "Satanic Verses" themselves); ${ }^{23}$ and an account about the evil eye with which Muhammad was inflicted (tusìibuhu layn) in Mecca before and after the revelation. ${ }^{24}$ Also an account about the rumours that Muhammad's son Ibrāhīm was fathered by a cousin of the child's mother, Māriya the Copt. 'Alī was ordered to kill the cousin if he found him with her. But the cousin managed to prove that he was gelded, thereby saving his life. ${ }^{25}$ Finally, an account about 'Umāra ibn al-Walīd's overtures to 'Amr ibn al-'Āṣ's wife, followed by 'Amr's terrible revenge. ${ }^{26}$

\section{Muḥammad and the holy man}

The following account (Ibn Bukayr $\leftarrow$ Ibn Ishāq) is missing in Ibn Hishām's epitome because it concerns a thing that is, according to Ibn Hishām, disgraceful to talk about. It describes a meeting between Muhammad, accompanied by his adopted son Zayd ibn Hāritha, and the hanif or "seeker of true religion" Zayd ibn "Amr ibn Nufayl::27

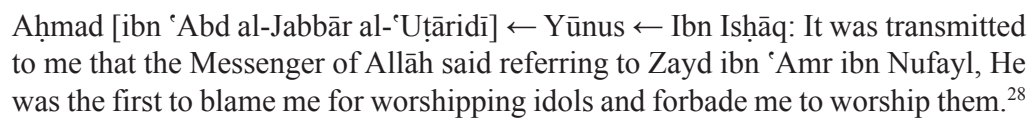

23 Ibn Isḥāq, Sìra, ed. Ḥamīdullāh, pp. 157-158, no. 219; Ibn Isḥāq, Kitāb al-siyar wa-l-maghāzì , ed. Zakkār, pp. 177-178; Guillaume, New Light on the Life of Muhammad, pp. 38-39; Ahmed, "Satanic Verses".

${ }^{24}$ Ibn Isḥāq, Sìra, ed. Hamīdullāh, p. 104, no. 143; Ibn Ishāq, Kitāb al-siyar wa-lmaghāzī, ed. Zakkār, p. 124; Guillaume, New Light on the Life of Muhammad, pp. 29, 59.

${ }^{25}$ Ibn Isḥāq, Sìra, ed. Ḥamīdullāh, p. 252, no. 412; Ibn Isḥāq, Kitāb al-siyar wa-lmaghāzì, ed. Zakkār, p. 271.

${ }^{26}$ Ibn Isḥāq, Sìra, ed. Hamīdullāh, pp. 148-50, no. 211; Ibn Isḥāq, Kitāb al-siyar wal-maghāzī, ed. Zakkār, pp. 167-170; Guillaume, New Light on the Life of Muhammad, pp. 36-37.

27 See his long entry in Ibn 'Asākir, Ta'rìkh madīnat Dimashq, ed. al-'Amrawī, XIX, pp. 493-516. See also Rubin, The Eye of the Beholder, pp. 47-48, 77-81, 88. Rubin discussed various aspects relating to the versions of Zayd's meeting with Muhammad. The evidence regarding Zayd is unique and calls for a separate analysis.

${ }^{28}$ The partial parallel text in al-Rabīi ibn Habīb al-Azdì al-Bașrī, al-Jāmi al-șahìh musnad al-imām al-Rabī' ibn Habīb, ed. Muhammad Idrīs \& 'Āshūr ibn Yūsuf, p. 44 is even more explicit at this point through the addition of one word: 'äba 'alayya 'ibādata l-așnäm; below, Appendix VI. The contemporary editors of this Musnad could not accept the account at face value and denied that Muhammad had taken part in his tribe's idol wor- 
I had come from Ṭā'if with Zayd ibn Hāritha and passed by Zayd ibn 'Amr while he was in Upper Mecca ( $\left.a^{\prime} l \bar{a} M a k k a\right) .{ }^{29}$ The Quraysh had rendered him notorious for abandoning their religion, until he went forth from among them and lived in Upper Mecca. I sat near him with a leather bag (sufra) carried by Zayd ibn Hāritha that contained meat from our sacrifices to our deities. I offered it to him - I was a young lad (ghulàm shābb) at that time ${ }^{30}$ - and said, Have some of this food, uncle. He said, Nephew, perhaps it is from the animals that you sacrifice to your idols? I said, Yes. He said, Nephew, had you asked 'Abd al-Mutțalib's daughters [i.e. Muhammad's paternal aunts ${ }^{31}$, they would have told you that I never eat of these sacrifices and do not need them. Then he denigrated the idols and those who worshipped them and sacrificed to them. He said, They are nothing but falsehood and do neither harm nor good, or words to that effect. The Messenger of Allāh said, After that I never stroked any of the idols (to draw blessing from it), having become aware of them, ${ }^{32}$ nor did I sacrifice to them until Allāh to Him belongs glory and power honoured me with his Mission. ${ }^{33}$

Half a century ago Guillaume correctly described the account as one of outstanding importance and added that it had been expunged from Ibn Hishām's recension. He also remarked that "[i]t is the only extant evidence of the influence of a monotheist on Muhammad by way of admonition," ${ }^{34}$ implying that it is factual. But it appears - and further research on this matter is needed - that those who were interested in glorifying the holy man, above all his descendants, were prepared to achieve their goal, so to speak, at Muhammad's expense.

ship: qawluhu 'äba 'alayya bi-tashdìd al-yā' ay dhakara 'ayb dhālika 'indì wa-lam yakun danā mina l-așnām shay'an wa-lā dhabaha 'alayhā wa-lākin kāna qawmuhu yaf'alūna dhālika fa-zanna Zayd ibn 'Amr anna l-sīra wāhida wa-dhālika qabla l-nubuwwa fa-lihādhā dhakara 'aybahā 'indahu wa-huwa ṣl'm lam yazal musaddadan muwaffaqan.

29 The place is also called al-Ma'lāt. Cf. Guillaume, New Light on the Life of Muhammad, p. 27: "on a high ground above Mecca". The borders of al-Ma'lāt and al-Masfala are defined in al-Azraqī, Akhbār Makka wa-mā jā'a fìhā min al-āthār, ed. Rushdī Malhas, II, p. 266. Mt. Hirā' is in A'lā Makka; Ibn 'Asākir, Dimashq, XIX, p. 495. Incidentally, according to some, Zayd was buried at the bottom of Mt. Hiirā'; Ibn 'Asākir, Dimashq, XIX, p. 516.

${ }^{30}$ This indicates that the event is supposed to have taken place many years before the Mission.

31 The mention of the aunts is yet another indication of Muhammad's young age. The tone is rather offensive.

${ }^{32}$ The phrase 'alā ma'rifa bihā is obscure.

33 Ibn Ishāa, Sìra, ed. Hamīdullāh, p. 98, no. 133; Ibn Ishāq, Kitāa al-siyar wa-l-maghāzī, ed. Zakkār, p. 118. The text and its omission by Ibn Hishām were discussed in Rubin, The Eye of the Beholder, pp. 79-81. See the parallel text in Ibn 'Asākir, Dimashq, XIX, p. 507; below, Appendix VII.

${ }^{34}$ Guillaume, New Light on the Life of Muhammad, pp. 27-28, 59. 
Medieval scholars considered the account problematic. Al-Harbi (d. 285/898) expressed unease about the reports that Muhammad had consumed the meat of animals sacrificed to an idol. Perhaps Zayd ibn Hāritha sacrificed the animal at his own initiative, or Zayd innocently slaughtered it where an idol happened to be located. Allāh forbid, alHarbi said, that we should adopt the outward meaning of the account. ${ }^{35}$ Al-Suhayli (d. 581/1185) wondered how Allāh guided Zayd to refrain from eating what had been sacrificed to idols, while Muhammad had the better right to such guidance. ${ }^{36}$ There is perhaps evidence of contemporary censorship regarding this matter. In the manuscript of alKhargūshī's Sharaf al-muștafā quoted by M.J. Kister we find Zayd ibn Haaritha's following statement: "The Prophet slaughtered a ewe for a certain idol; then he roasted it and carried it with him". ${ }^{37}$ The printed edition of this book has a milder version, according to which it was not Muhammad who roasted the ewe but his companions. ${ }^{38}$

${ }^{35}$ Fa-ammā zạhir mā jă'a bihi l-hadìth fa-ma ādha llāhi; al-Harbì, Gharìb al-hadìth, ed. Sulaymān ibn Ibrāhīm al-'Āyid, s.v. n.ș.b., II, pp. 791-792. Al-Dhahabī, Siyar a'lām al-nubalā', ed. Shu'ayb al-Arnāwūt et al., I, p. 127 denied that Zayd had followed Ibrāhīm's sharī'a properly or met someone who could initiate him into it: wa-qāla llahumma innì 'alā dīn Ibrāhīm, wa-lākin lam yazfar bi-sharī'at Ibrāhīm 'alayhi l-salām kamā yanbaghì wa-lā ra'ā man yūqifuhu 'alayhā. Al-Dhahabì also argued (pp. 130-131) that Muhammad had eaten the sacrifices of his tribe before the first revelation, when it was still permitted, exactly as wine had been lawful before it was forbidden.

36 Al-Suhaylī, al-Rawd al-unuf, ed. Țāhā 'Abd al-Rā'ūf Sa'd, I, p. 256; Guillaume, New Light on the Life of Muhammad, pp. 27-28. Kister ("'A bag of meat': A study of an early hadith," pp. 274-275) concluded that the discussion concerned "the essential problem of the "isma of the Prophet before he was granted prophethood. The main effort of the Muslim scholars was to prove that the Prophet did not eat meat slaughtered for idols, nor did he slaughter it, as he was granted immunity from sin before he received prophethood". Kister (p. 275) remarked regarding a detailed account in the same vein found in al-Khargūshì's Sharaf al-mustafăa: "The tradition of al-Khargūshī based on the idea that the Prophet had no 'isma before his Mission belongs to the earliest layer of hadith - traditions which fell later into oblivion or were re-shaped or expunged". See al-Khargūshī, Sharaf almuștafă, ed. Nabīl Āl Bāealawī, I, pp. 455-460, no. 174.

37 Kister, "A bag of meat," p. 270, quoting MS British Museum 3014: dhabaha rasūlu llāh șallā llāhu 'alayhi wa-sallama shātan li-nușub mina l-anșāb, qāla: thumma shawāhā fa-'htamalahà ma'ahu.

38 Al-Khargūshī, Sharaf al-muștafā, I, pp. 456-457: kharaja bì l-nabì șl'm wa-huwa murdifi ilā nușub mina l-anșāb fa-dhabahnna lahu shātan fa-andajnāhā. The edition is based on "three copies from remote countries;" al-Khargūshī, Sharaf al-muștafā, I, p. 6. 


\section{The harlot from Yathrib and her jinnī}

The following account (Ibn Bukayr $\leftarrow$ Ibn Ishāq) was expunged from Ibn Hishām's epitome because it concerns a thing that may, according to Ibn Hishām, distress certain people:

Aḥmad [ibn 'Abd al-Jabbār al-'Uțāridī] $\leftarrow$ Yūnus $\leftarrow$ Ibn Isḥāq: The Anșār used to say about what they would hear from the Jews concerning the Messenger of Allāh: The first mention [of the Mission] in Medina before the Mission of the Messenger of Allāh was this: Fātịma mother of al-Nu'mān ibn 'Amr of the Banū

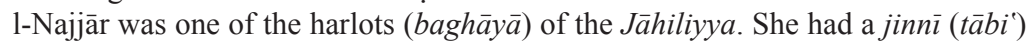
and used to say that whenever he came to her, he would storm (iqtahama) into the room in which she was, regardless of the others who were in it [for whom he was invisible]. ${ }^{39}$ [This went on] until he came to her one day, collapsed on the wall and did not do what he usually did [i.e. have intercourse with her]. She said to him, What's the matter with you today? He said, A prophet was sent prohibiting harlotry. ${ }^{40}$

The jinnī's admission of defeat means that the prohibition of harlotry went into force with immediate effect, and hence he could no longer continue his former way of life. The story shows that in pre-Islamic Medina a love affair between a jinnī male and a woman was not unthinkable. Obviously the woman in question gained special spiritual powers through her jinni. ${ }^{41}$ The account was included in Ibn Ishāa's biography of Muhammad not because of the light that it sheds on pre-Islamic Medinan society, but because it belongs to the dalā'il al-nubuwwa or the proofs of Muhammad's prophethood. More specifically, it belongs to the dala' $i l$ subgroup that includes testimonies of jinnīs who realized through the loss of their special status and powers that the world had changed for good.

${ }^{39}$ Guillaume, New Light on the Life of Muhammad, p. 26: "[Whenever] he came to her, the house became intensely dark to those who were in it". Guillaume opted for the reading iftahama instead of iqtahama, although he admitted that the former could not be found in the lexicons.

${ }^{40}$ Ibn Ishāa, Sìra, ed. Hamīdullāh, p. 92, no. 122; Ibn Ishāa, Kitāb al-siyar wa-l-maghāzī, ed. Zakkār, p. 113; Guillaume, New Light on the Life of Muhammad, pp. 25-26; below, Appendix VIII.

${ }^{41}$ Jinnī females were said to have married humans: 'Amr ibn Yarbū' ibn Hanzala of the Tamìm had a jinnī wife; Wellhausen, Reste arabischen Heidentums, p. 154. In Wellhausen, Reste arabischen Heidentums, n. 1, with regard to the kidnapping of Sinān ibn Abì Hâaritha by the jinn to be used as "stallion," there is a misprint: read istafhalathu instead of istaflahathu; see. e.g. Ibn 'Asākir, Dimashq, XVI, pp. 338-339. 
Fātima's occupation is a background detail, and as such it is trustworthy. Her pedigree which is found in an entry about her son, al-Nu'(ay)mān ibn 'Amr runs as follows: Fāțima bint 'Amr ibn 'Ațiyya ibn Khansā' ibn Mabdhūl ibn 'Amr. The pedigree shows that she belonged to the Najjār branch of the Khazraj, more precisely to the Māzin ibn al-Najjār subsection. ${ }^{42}$ Her husband belonged to another subsection of the Najjār, namely Ghanm ibn Mālik ibn al-Najjār. His pedigree is: 'Amr ibn Rifāea ibn al-Ḥārith ibn Sawād ibn Ghanm ibn Mālik ibn al-Najjār. Their son al-Nu'(ay)mān was a companion of Muhammad with a penchant for practical jokes and a drinking problem. ${ }^{43}$

There are two other versions regarding the harlot's identity. While confirming that she was from the Najjār, they offer no pedigree and probably aim at obscuring her identity so as to protect her family's reputation. One source calls her Fukayha of the Najjār, ${ }^{44}$ while another source, which similarly states her Najjārī affiliation, calls her Fāṭima bint al-Nu mān. ${ }^{45}$ According to al-Suhaylī, the woman was referred to as Fātima bint al-Nu 'mān in a recension of Ibn Isḥāq's biography other than al-Bakkā'î's. ${ }^{46}$ Beside the woman's name there are several

${ }^{42}$ Ibn Sa'd, al-Tabaqāt al-kubrāa, Beirut, III, p. 493.

${ }^{43}$ Ibn Sa'd, al-Tabaqāt al-kubrā, Beirut, III, pp. 493-494. When he was drunk, he killed a fellow member of the Najjār; Ibn 'Asākir, Dimashq, LXII, p. 148. It may be of interest that he had nine children born by different slave girls and only one born by a freeborn woman; Ibn Sa'd, al-Tabaqāt al-kubrāa, Beirut, III, p. 493. One or two years before Muhammad's death he reached Bușrā with Abū Bakr and another Qurashī called Suwaybit on a trading mission, which is why Ibn 'Asākir, Dimashq, LXII, pp. 139-149 included him in his History of Damascus. For entries on Suwaybit see e.g. Ibn Manzūr, Mukhtasar ta'rīkh Dimashq li-Ibn 'Asākir, ed. Rūhiyya al-Naḥhāas et alii, X, pp. 213-214; Ibn Ḥajar, Iṣāba, s.v., III, pp. 222-223. Guillaume argued (New Light on the Life of Muhammad, p. 25, n. 3) that the harlot's son was a Jew who was hostile to Muhammad. He concluded (New Light on the Life of Muhammad, p. 26) that Jews were regarded as members of the Najjār, the tribe of the prophet's maternal relations. But the Jew al-Nu'mān ibn 'Amr belonged to the Qaynuqāe; Ibn Hishām, Das Leben Muhammeds, pp. 352, 383.

${ }^{44}$ Khalīfa ibn Khayyāt, Tabaqāt, ed. Akram Diyā' al- 'Umarī, p. 87.

${ }^{45}$ Ibn Sa'd, al-Tabaqāt al-kubrā, I, Beirut, p. 167; below, Appendix IX. Ibn Sa'd quotes a series of dalä'il al-nubuwwa accounts including this one from 'Alì ibn Muhammad al-Madā'inī. Three of al-Madā'inī's accounts go back to 'Alī ibn Mujāhid who at some time officiated as the $q \bar{a} d \bar{l}$ of Rayy. According to some, he had a bad reputation as a hadith transmitter and compiled a book entitled Kitāb al-maghāzī; al-Mizzī, Tahdhīb al-kamāl, ed. Bashshār 'Awwād Ma'rūf, XXI, pp. 117-120. Two of the three accounts go back to Muḥammad ibn Isḥāq. See also al-Damìrī, Hayāt al-ḥayawān al-kubrā, I, p. 294; below, Appendix X. 
other differences between the text that al-Suhayli quoted from the unspecified recension of Ibn Ishāq and Ibn Bukayr's text. This shows that at least two recensions of Ibn Ishạa's biography contained this account.

Harlotry must have been common in pre-Islamic Arabia, especially in connection with its markets and fairs. But the case of Fātima is of special interest, because harlots were usually slave girls, not freeborn women. ${ }^{47}$

A similar account of a jinnī relates to an unspecified woman in Mecca who belonged to the Asad ibn 'Abd al- 'Uzzā branch of the Quraysh tribe. Her jinni informed her of an unbearable grave matter that had occurred, namely that Ahmad (i.e. Muhammad) had prohibited harlotry. When Allāh brought Islam, they (i.e. the jinnīs) were barred from eavesdropping ${ }^{48}$ i.e. they could no longer listen and uncover the goings on in Heaven. ${ }^{49}$

Ibn Ishāa's account about the harlot from Yathrib/Medina could indeed distress certain people, i.e. her direct descendants and her other family members.

According to an account found in Abū l-'Arab's Kitāb al-mihan, Ibn Ishāq was flogged twice by the governor of Medina for disclosing faults in the genealogy of his fellow Medinans: "He was an expert on genealogy and no family in Medina was spared the faults that he discovered in its genealogy. Hence the people of Medina treated him with hostility". The governor of Medina had him flogged once, but he did

46 Al-Suhaylī, Rawd, I, p. 239; below, Appendix XI. The story of Fātima bint alNu'mān is also found in Ibn al-Jawzī, al-Wafă bi-ahwāl al-muștafāa, ed. Mușțafā 'Abd alWāhid, p. 154 where it is preceded by an account along the same lines ( $\leftarrow$ Jäbir) in which the woman's name and tribal affiliation are unspecified and the jinnī has the form of a bird.

$47 \mathrm{Cf}$. the so-called "harlots of Hadramawt". Upon hearing of Muhammad's death, twenty-odd harlots (baghāya) emulated six women from the Kinda and Hadramawt; the latter rejoiced by dying their hands with henna and playing on tambourines. A parallel text refers to these women as singing girls (qiyān) from the Kinda and prostitutes ('awāhir) from the Hadramawt who dyed their hands, exposed their charms and played on tambourines. In fact they were respectable women of various Kindite and Hadramite clans; Lecker, "Judaism among Kinda and the ridda of Kinda," pp. 646-649.

48 Ibn Sa d, al-Ṭabaqāt al-kubrā, I, Beirut, p. 167; below, Appendix XII.

49 Chabbi, "Jinn". 
not give up his genealogical research and was flogged again. ${ }^{50} \mathrm{Ibn}$ Ishāq comes through as a man who did not shy away from treading on people's toes and had no fear of the Umayyad governor. Ibn Ishāa's character and, as it were, his origin - his grandfather was Jewish ${ }^{51}$ are comparable to those of another famous mawlāa, namely Abū 'Ubayda Ma'mar ibn al-Muthannā (d. 210/825) who was similarly of Jewish descent. The latter made himself extremely unpopular by specializing, among other topics, in mathālib or "faults," often those linked to genealogy. ${ }^{52}$

Ibn Hishām, who must have been a more conventional person, omitted many of his predecessor's materials, which probably contributed to the popularity of his epitome. Beside improper verses he also expunged details and accounts that were incongruous with Muhammad's image, or could offend the offspring of Muhammad's companions. Censorship and self-censorship applied in Ibn Ishāa's biography of Muhammad and in its epitome belong to the social and political context of both books.

\section{Appendices}

Appendix I: Ibn Hishām, Das Leben Muhammeds, 898-899

قال ابن اسحاق وقد كان رسول الله صلعم حين مر بالحِجْر نزلها واستقى الناس من بير ها فلما راحوا قال رسول اله صلعم لا تتربو ا من مائها شيئا ولا نتوضؤوا منه تهن للصلاة وما كان من عجين عجنتموه فاعلفوه الإبل و لا تأكلوا منه شيئا ولا يخرجن أحد منكم الليلة إلا ومعه صاحب له ففعل الناس ما أمر هم به رسول الله صلعم إلا أنَّ رجلين من بني ساعدة خرج أحدها لحاجته وخرج الآخر في طلب بعير له فأما

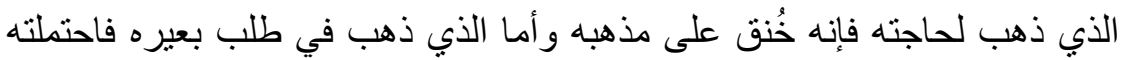
الريح حتى طرحته بجبليْ طيء فأخبر بذلك رسول الله صلعم فقال ألم أنهم أن

${ }^{50}$ Abū l-'Arab al-Tamīmī, Kitāb al-mihan, ed. Yaḥyā Wahīb al-Jabbūrī, pp. 377-378.

${ }^{51}$ Lecker, "Muḥammad ibn Isḥāq șạhị al-maghāzī: was his grandfather Jewish?" (forthcoming).

${ }^{52}$ Lecker, "Biographical notes on Abū 'Ubayda Ma'mar b. al-Muthannā". 
يخرج منكم أحد إلا ومعه صاحبه ثم دعا للأب أصيب على مذهبه فثفي وأما الآخر الذي وقع بجبلئ طيء فإن طيئا أهدته لرسول الله صلعم حين قدم 53 المدينة. و الحديث عن الرجلين عن عبد الله بن أبي بكر عن عباس بن سهل بن سعد الساعدي لهاي وقد حدثني عبد الله بن أبي بكر أن قد سمَّى له العباسُ الرجلين ولكنه استودعه إياهما فأبي عبد الله أن يسميهما لي.

Appendix II: Wāqidīi, Maghāzī, III, 1005-1006

قال أبو حُميد الساعدي خرجنا مع رسول الهه صلى الله عليه وسلم إلى تبوك فلما جئنا وادي القرى مررنا على حديقة لامرأة فقال رسول الله صلى الله عليه وسلم اخرصو ها فخرصها رسول الله صلى الله عليه وسلم وخرصناها معه عشرة أوساق ثم قال رسول الله صلى الله عليه وسلم احفظي ما خر جنها حتى نرجع إليك.

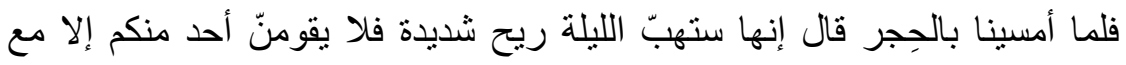

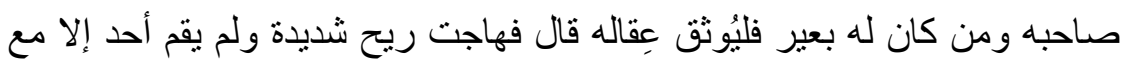
صاحبه إلا رجلين من بني ساعدة خرج أحدهما لحاجته وخرج الآخر في طلب

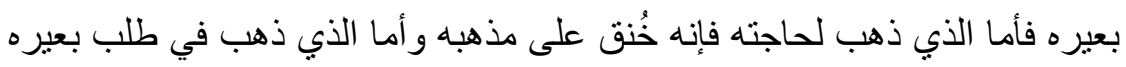
فاحتملته الريح فطرحته بجبليْ طيء فأخبر رسول الله صلى الله عليه وسلم خبر هما

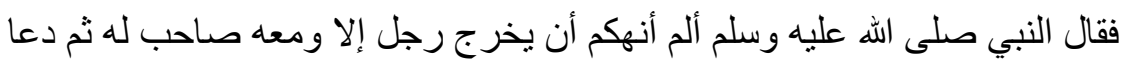
الذي (!) أصيب على مذهبه فثفي و أما الآخر الذي وقع بجبليْ طيء فإن طيئا أهدنه للنبي صلى الله عليه وسلم حين قدم المدينة.

53 Add فوها?

Al-Qanțara XXXV 1, 2014, pp. 233-254 ISSN 0211-3589 doi: 10.3989/alqantara.2013.010 
Appendix III: Ibn Zanjawayh, Amwāl, III, 1076-1077, no. 2001

أخبرنا حميد أنا ابن أبي أويس أنا أخي عن سليمان بن بلال عن عمرو بن يحيى

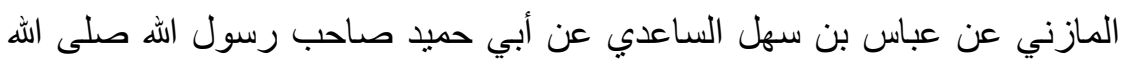
عليه وسلم أن رسول الله صلى الله عليه وسلم خرج إلى تبوك قال أبو حميد وخرجنا

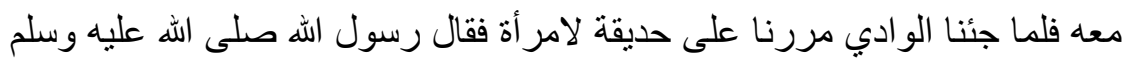
اخرصو ها فخرصناها وخرصها رسول الله صلى الله عليه وسلم عثرة أوسق ثم قال لها احتفظي بما يخرج منها حتى نرجع إليك فلما رجعنا مررنا على المرأة فسألها رسول الله صلى الله عليه وسلم عما خرج من حديقتها فقالت خرج منها عشرة

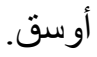

Appendix IV: Muslim’s Șaḥịh, IV, 1785-1786 (Kitāb al-faḍ̂̀̉il, no. 11) حدثنا عبد الله بن مسلمة بن قعنب حدثنا سليمان بن بلال عن عمرو بن بحيى عن عباس بن سهل بن سعد الساعدي عن أبي حميد قال خرجنا مع رسول الله صلى الله بله بـ بله عليه وسلم غزوة تبوك فأتينا وادي القرى على حديقة لامر أة فقال رسول الله صلى على رسي الله عليه وسلم اخرصو ها فخرصناها وخرصها رسول الله صلى الله عليه وسلم

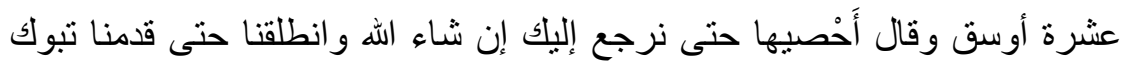

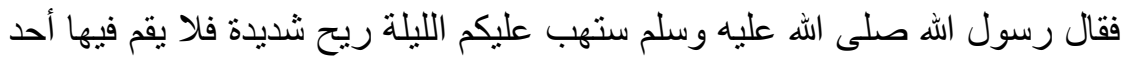
منكم فمن كان له بعير فليشد عِقاله فهبت ريح شديدة فقام رجل فحملته الريح حتى ألقته بجبليْ طيء وجاء رسول ابن العَلْماء صاحب أيلة إلى رسول الله صلى الله عليه وسلم بكتاب و أهدى له بغلة بيضاء فكتب إليه رسول الله صلى الله عليه وسلم وأهدى لله بردا ثم أقبلنا حتى قدمنا وادي القرى فسأل رسول الله صلى الله عليه وسلم المر أة عن حديقتها كم بلغ ثمر ها فقالت عشرة أوسق. 
Appendix V: Ibn Hishām, Das Leben Muhammeds, 4

و أنا إن شاء الله مبتدئ هذا الكتاب بذكر إسماعيل بن إبراهيم ومن وَلاّ رسولَ الله صلعم من ولده وأو لادهم لأصلابهم الأول فالأول من إسماعيل إلى رسول الله صلعم

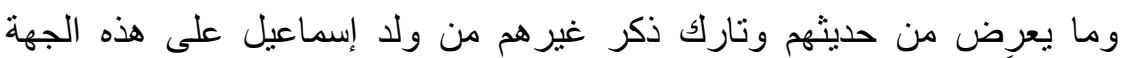
للاختصار إلى حديث سيرة رسول الله صلعم ونارك بعض ما ذكره ابن إسحاق في ملي هذا الكتاب مما ليس لرسول الله صلعم فيه ذكر وما نزل فيه من القر آن شيء وليس سببا لثيء من هذا الكتاب و لا تفسير اله و لا شاهدا عليه لما ذكرت من الاختصـار و أثعار ا ذكرها لم أر أحدا من أهل العلم بالثعر بعرفها وأثباء بعضها يشنُع الحديث به وبعضٌُ يسوء بعضَ الناس ذكره وبعضُّ لم يقر لنا البكائي بروايته ومستقص إن شاء الله تعالى ما سوى ذللك بمبلغ الرواية له و العلم به.

Appendix VI: Al-Rabīi ibn Ḥabīb, Musnad, 44

قال الربيع قال أبو عبيدة54 بلغني عن النبي صلى اله عليه وسلم قال إنْ كان زيد بن عمرو لأول من عاب علي عبادة الأصنام و الذبح عليها وذللك أني أقبلت من الطائف ومعي زيد بن حارثة ومعنا خبز ولحم وكانت قريش آذت زيد بن عمرو حتى خرج من بين أظهرنا فمررت بهه و عرضت عليه السفرة فقال يا ابن أخي أنتم تذبحون على ودئ

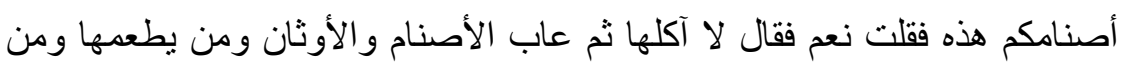
يدنو منها 55 قال رسول الله صلى الله عليه وسلم و الله ما دنوت من الأصنام شيئا حتى ولى أكرمني الله بالنبوة.

${ }^{54}$ I.e. Abū Ubayda Muslim ibn Abī Karìma al-Tamīmī. See on him Francesca, "The formation and early development of the Ibāẹi madhhab," p. 262, n. 13; Francesca, "Khārijis".

55 Kister, “A bag of meat," p. 270: "approached them with reverence”. 
Appendix VII: Ibn `Asākir, Dimashq, XIX, 507

نا آحمد نا يونس عن ابن إسحاق قال فحدثت آن رسول اله صلى الله عليه وسلم قال و هو يحدث عن زيد بن عمرو إن كان لأول من عاب عليَّ الأوثان ونهاني عنها أقبلت من الطائف ومعي زيد بن حارثة حتى مررت بزيد بن عمرو بن نفيل وهو بأعلى مكة وكانت قريش قد شهرته بفر اق دينها حتى خرج من بين أظهر هم وكان بأعلى مكة فجلست إليه ومعي سفرة لي فيها لحم يحملها زيد بن حارثة من ذبائحنا على أصنامنا فقربتها له و أنا غلام شاب فقلت كل من هذا الطعام أي عم قال فلعلها أي ابن أخي من ذبائحكم هذه التي تذبحون لأوثانكم فقلت نعم فقال أما إنك يا ابن أخي لو سألت بنات عبد المطلب لأخبرنك أني لا آكل هذه الذبائح فلا حاجة لي بها

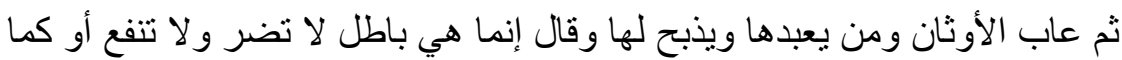
قال قال رسول الله صلى الله عليه وسلم فما تمسحت بوثن منها بعد ذلك على معرفة بها و لا ذبحت لها حتى أكرمني الله تعالى برسالته صلى الله عليه وسلم.

Appendix VIII: Ibn Isḥāq, Sìra, ed. Hamīdullāh, 92, no. 122

حدثنا أحمد نا يونس عن ابن إسحاق قال وكان هذا الحي من الأنصار يتحثثون مما كانو ا يسمعون من يهود من ذكر رسول الله صلى الله عليه وسلم أن أول ذكر وقع اله

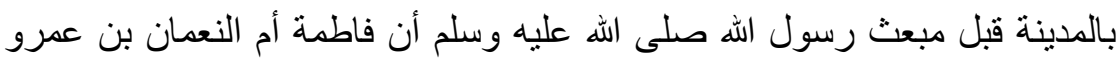
أخي بني النجار وكانت من بغايا الجاهلية وكان لها تابع فكانت تحدث أنه كان إذا جاءها اقتحم البيت الذي هي فيه اقتحاما على من فيه حتى جاءها يوما فوقع على بهى بهابـ الجدار ولم يصنع كما كان يصنع فقالت لله ما للك اليوم قال بعث نبي بتحريم الزنا. 
Appendix IX: Ibn Sadd, al-Ṭabaqāt al-kubrāa, I, 167

أخبرنا علي بن محمد عن علي بن مجاهد عن محمد بن إسحاق عن عاصم بن عمر

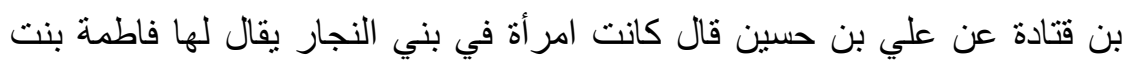

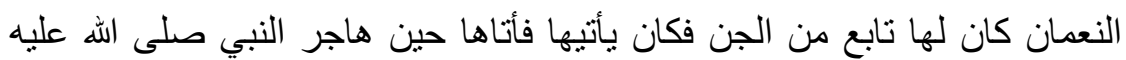
وسلم فانقض على الحائط فقالت ما للك لم تأت كما كنت تأتي قال قد جاء النبي الذي لـاني يحرم الزناو الخمر.

Appendix X: al-Damīīi, Hayāt al-Hayawān, I, 294

وفيه أيضا أن فاطمة بنت النعمان النجارية قالت قد كان لي تابع من الجن فكان إذا جاء اقتحم البيت الذي أنا فيه اقتحاما فجاءني يوما فوقف على الجدار ولم يصنع كما كان يصنع فقلت ما باللك لم تصنع ما كنت تصنع صنيعك قبل فقال إنه قد بعث اليوم نبي يحرم الزنا.

Appendix XI: al-Suhaylī, Rawd, I, 239

وفي غير رواية البكائي عن ابن إسحا ق أن فاطمة بنت النعمان النجارية كان لها تابع من الجن وكان إذا جاءها اقتحم عليها في بيتها فلما كان في أول البعث أتاها فقعد على حائط الدار ولم يدخل فقالت له لم لا تدخل فقال قد بعث نبي بتحريم الزنا فذلك أول ما ذكر النبي صلعم بالمدينة.

Appendix XII: Ibn Sa'd, al-Ṭabaqāt al-kubrāa, I, 167

آخبرنا علي بن محمد عن عبد الله بن محمد القرشي من بني آسد بن عبد العزى عن

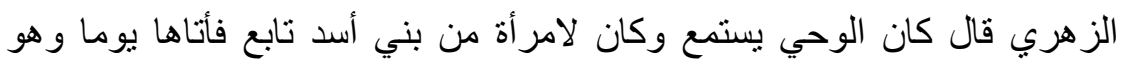

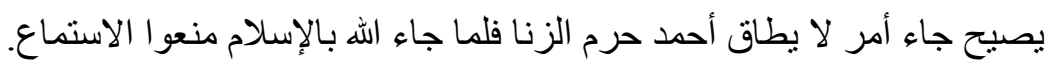




\section{Sources and bibliography}

\section{Sources}

Abū 1-'Arab al-Tamīmī, Kitāb al-mihan, Yahyā Wahīb al-Jabbūrī (ed.), Beirut, Dār al-Gharb al-Islāmī, 1403/1983, 2nd ed.

Al-Azraqī, Akhbār Makka wa-mā jā'a fìhā min al-āthār, Rushdī Malhas (ed.), [Beirut], Dār al-Andalus, n.d.

Al-Damīrī, Hayāt al-ḥayawān al-kubrāa, Cairo, Mușțafā al-Bābī al-Halabī, 1389/1969, 2 vols.

Al-Dhahabī, Siyar a'lām al-nubalā', Shu'ayb al-Arnāwūt et al. (ed.), Beirut, alRisāla, 1401/1981-1409/1988, 25 vols.

Al-Ḥarbī, Gharīb al-ḥadìth, Sulaymān ibn Ibrāhīm al-`Āyid (ed.), Mecca, Jāmieat Umm al-Qurā, 1405/1985, 3 vols.

Ibn 'Asākir, Ta'rīkh madīnat Dimashq, 'Umar ibn Gharāma al-'Amrawī (ed.), Beirut, Dār al-Fikr, 1415/1995-1419/1998.

Ibn Hajar, al-Iṣāba fì tamyīz al-ṣahāba, al-Bijāwī (ed.), Cairo, Dār Nahḍat Miṣr, 1392/1972, 8 vols.

Ibn Hazm, Jamharat ansāb al-'arab, 'Abd al-Salām Hārūn (ed.), Cairo, Dār alMaēarif, 1382/1962.

Ibn Hishām, Das Leben Muhammeds nach Muhammed ibn Ishâk, bearbeitet von Abd el-Malik ibn Hischâm, F. Wüstenfeld (ed.), Göttingen, Dieterichsche Universitäts-Buchhandlung, 1858-60, 3 vols.

Ibn Ishāq, Kitāb al-siyar wa-l-maghāzī, Suhayl Zakkār (ed.), Beirut, Dār al-Fikr, 1398/1978.

Ibn Isḥāq, Sìrat Ibn Ishạa al-musammāt bi-kitāb al-mubtada' wa-l-mab'ath wal-maghāzī, Muḥammad Hamīdullāh (ed.), n. p., Ma`had al-Dirāsāt wa-l-Abhāth li-1-Ta rīb, 1396/1976.

Ibn al-Jawzī, al-Wafă bi-ahwāl al-muștafā, Muștafā 'Abd al-Wāhid (ed.), Cairo, Dār al-Kutub al-Hadìtha, 1386/1966.

Ibn Manẓūr, Mukhtașar ta'rīkh Dimashq li-Ibn 'Asākir, Rūḥiyya al-Naḥhāas et alii (ed.), Damascus, Dār al-Fikr, 1404/1984-1409/1989, 15 vols.

Ibn Sa'd, al-Ṭabaqāt al-kubrā, Beirut, Dār Șādir \& Dār Bayrūt, 1380/19601388/1968, 8 vols.

Ibn Sa d, al-Ṭabaqāt al-kubrā: al-qism al-mutammim li-tābi ì ahl al-Madīna waman ba'dahum, Ziyād Muhammad Manșūr (ed.), Medina, Maktabat al-'Ulūm wa-l-Hikam, 1408/1987.

Ibn Zanjawayh, Kitāb al-amwāl, Shākir Dhīb Fayyāḍ (ed.), Riyadh, King Faisal Center, 1406/1986, 3 vols.

Khalīfa ibn Khayyāt, Țabaqāt, Akram Ḍiyā' al-'Umarī (ed.), Riyadh, Dār Ṭayba, 1402/1982.

Al-Khargūshī, Sharaf al-muștafāa, Nabīl Āl Bāalawī (ed.), [Beirut], Dār alBashā'ir al-Islāmiyya, 1424/2003, 6 vols. 
Al-Mizzī, Tahdhīb al-kamāl, Bashshār 'Awwād Ma'rūf (ed.), Beirut, al-Risāla, 1405/1985-1413/1992, 35 vols.

Muslim ibn al-Hajjāj, Șahīh, Muḥammad Fu'ād 'Abd al-Bāqī (ed.), Cairo, 'Īsā alBābī al-Halabī, 1374/1955-1375/1956, 5 vols. Reprint Beirut, Dār Ihyyā' alTurāth al-'Arabī.

Al-Rabīi ibn Habīb al-Azdī al-Bașrī, al-Jāmi al-ṣah̄h musnad al-imām al-Rabī ibn Habīb, Muhammad Idrīs and 'Āshūr ibn Yūsuf (ed.), Beirut, Dār al-Ḥikma \& 'Ümān, Maktabat al-Istiqāma, 1415/1995.

Al-Suhaylī, al-Rawd al-unuf, Țāhā 'Abd al-Rā'ūf Sa'd (ed.), Cairo, Maktabat alKulliyyāt al-Azhariyya, 1391/1971, 4 vols.

Al-Ṭabarī, Ta'rīkh al-rusul wa-l-mulūk, de Goeje et alii (ed.), Leiden, Brill, 18791901, 15 vols.

Al-Wāqidī, Kitāb al-maghāzī, Marsden Jones (ed.), London, Oxford University Press, 1966, 3 vols.

\section{Bibliography}

Ahmed, Shahab, "Satanic Verses," in Jane Dammen MacAuliffe Encyclopaedia of the Qur'ān, IV, Leiden-Boston, Brill, 2004, pp. 531-536.

Chabbi, J., "Jinn," in Jane Dammen MacAuliffe, Encyclopaedia of the Qur'ān, III, Leiden-Boston, Brill, 2003, pp. 43-50.

Francesca, E., "Khārijīs," in Jane Dammen MacAuliffe, Encyclopaedia of the Qur'ān, III, Leiden-Boston, Brill, 2003, pp. 84-90.

Francesca, E., "The formation and early development of the Ibāḍi madhhab," JSAI, 28 (2003), pp. 260-277.

Fück, J., Muhammad ibn Ishaq: Literarhistorische Untersuchungen, Frankfurt am Main, 1925, (dissertation).

Guillaume, A., New Light on the Life of Muhammad, Manchester University Press, 1960. Journal of Semitic Studies, Monograph No. 1.

Guillaume, A., The Life of Muhammad: A Translation of Ibn Ishāq 's Sìrat Rasūl Allāh, Oxford, Oxford University Press, 1955. Reprint Lahore \& Karachi, 1974.

Horovitz, J., The Earliest Biographies of the Prophet and their Authors, Princeton, Darwin Press, 2002.

Jarrar, M., Die Prophetenbiographie im islamischen Spanien: Ein Beitrag zur Überlieferungs- und Redaktionsgeschichte, Frankfurt a. M., Peter Lang, 1989.

Jones, J.M.B., "The Maghāzì literature," in The Cambridge History of Arabic Literature: Arabic Literature to the End of the Umayyad Period, A.F.L. Beeston, T.M. Johnstone, R.B. Serjeant and G.R. Smith (eds.), Cambridge, Cambridge University Press, 1983, pp. 344-351. 
Kister, M.J., “"A bag of meat': A study of an early hadith,” BSOAS, 33 (1970), pp. 267-275. Reprinted in M.J. Kister, Studies in Jāhiliyya and Early Islam, London, 1980, no. VI.

Kister, M.J., Studies in Jāhiliyya and Early Islam, London, Variorum, 1980.

Lecker, M., "Biographical notes on Abū 'Ubayda Ma'mar b. al-Muthannā," Studia Islamica, 81 (1995), pp. 71-100. Reprinted in Lecker, Jews and Arabs, Aldershot, 1998, no. XVIII (Variorum Collected Studies Series).

Lecker, M., Jews and Arabs in Pre- and Early Islamic Arabia, Aldershot, Variorum, 1998.

Lecker, M., "Judaism among Kinda and the ridda of Kinda," JAOS, 115 (1995), pp. 635-650. Reprinted in Lecker, Jews and Arabs, no. XIV.

Lecker, M., "Muḥammad ibn Isḥāq șâhib al-maghāzī: was his grandfather Jewish?" (forthcoming).

Muranyi, M., "Ibn Isḥāq's Kitāb al-Mag̀āzì in der Riwāya von Yūnus b. Bukair: Bemerkungen zur frühen Überlieferungsgeschichte," JSAI, 14 (1991), pp. 214-275.

Nöldeke, Th., "Die Tradition über das Leben Muhammeds,” Der Islam, 5 (1914), pp. 160-170.

Raven, W., "Sìra and the Qur'ān," in Jane Dammen MacAuliffe, Encyclopaedia of the Qur'ān, V, Leiden-Boston, Brill, 2006, pp. 29-51.

Rubin, U., The Eye of the Beholder: The Life of Muhammad as Viewed by the Early Muslims, Princeton, Darwin Press, 1995.

Al-Samuk, S.M., Die historischen Überlieferungen nach Ibn Ishāq. Eine synoptische Untersuchung, dissertation, Frankfurt a. M., 1978, (dissertation).

Schoeler, G., Charakter und Authentie der muslimischen Überlieferung über das Leben Mohammeds, Berlin-New York, de Gruyter, 1996.

Schoeler, G., The Genesis of Literature in Islam from the Aural to the Read, in collaboration with and translated by Shawkat M. Toorawa, Cairo, American University in Cairo Press, 2009.

Sezgin, F., Geschichte des arabischen Schrifttums, I, Leiden, Brill, 1967.

Wellhausen, J., Reste arabischen Heidentums, Berlin, 1897. Reprint Berlin, Walter de Gruyter, 1961.

Recibido: 29/07/2013

Aceptado: 21/01/2014 